\title{
Anti-cancer effects of Vernonia amygdalina: A systematic review
}

\author{
Julia Joseph¹, Vuanghao Lim¹, Heshu Sulaiman Rahman ${ }^{2,3}$, Hemn Hassan \\ Othman ${ }^{4}$, Nozlena Abdul Samad ${ }^{1 *}$ \\ ${ }^{1}$ Integrative Medicine Cluster, Institut Perubatan dan Pergigian Termaju (IPPT), Sains@BERTAM, Universiti Sains Malaysia, \\ 13200 Kepala Batas, Pulau Pinang, Malaysia, ${ }^{2}$ Department of Clinic and Internal Medicine, College of Veterinary Medicine \\ University of Sulaimani, ${ }^{3}$ Department of Medical Laboratory Sciences, College of Science, Komar University of Science and \\ Technology, ${ }^{4}$ Department of Pharmacology and Toxicology, College of Pharmacy, University of Sulaimani, Sulaymaniyah, \\ Republic of Iraq \\ *For correspondence: Email: nozlena@usm.my
}

\begin{abstract}
Purpose: To systematically review all the studies that have addressed the anti-cancer activities of the $V A$ leaf extract in vitro to determine the strength of evidence of its anti-cancer effects and whether it can be used as an effective cancer therapy.

Methods: The databases of Scopus, Science Direct, PubMed, Springer, and Directory of Open Access Journals were searched for relevant articles. Only articles published in the English language from January 2000 to November 2018 were selected for full-text retrieval and review, before being included in the final review.

Results: From a total of 28 articles identified for full-text retrieval, only 17 fulfilled the inclusion criteria. The papers reviewed showed that VA decreases cell viability, inhibits DNA synthesis and causes DNA damage in cancer cells. VA also induces apoptosis and cell cycle arrest in cancer cells via gene regulation. All in all, there is evidence showing that VA possesses time- and concentration-dependent anti-cancer activity.

Conclusion: The VA leaf extract has the potential to be developed into cancer therapeutics. However, more research is needed on its effect on normal cells before VA is developed into a cancer therapeutic.
\end{abstract}

Keywords: Vernonia amygdalina, Anti-cancer effect, DNA damage, Apoptosis

\begin{abstract}
This is an Open Access article that uses a fund-ing model which does not charge readers or their institutions for access and distributed under the terms of the Creative Commons Attribution License (http://creativecommons.org/licenses/by/4.0) and the Budapest Open Access Initiative (http://www.budapestopenaccessinitiative.org/read), which permit unrestricted use, distribution, and reproduction in any medium, provided the original work is properly credited.
\end{abstract}

Tropical Journal of Pharmaceutical Research is indexed by Science Citation Index (SciSearch), Scopus, International Pharmaceutical Abstract, Chemical Abstracts, Embase, Index Copernicus, EBSCO, African Index Medicus, JournalSeek, Journal Citation Reports/Science Edition, Directory of Open Access Journals (DOAJ), African Journal Online, Bioline International, Open-J-Gate and Pharmacy Abstracts

\section{INTRODUCTION}

Cancer prevalence and mortality rates are on the increase globally. However, with the improvement of cancer therapeutics, the proportion of cancer patients who survive for more than five years after diagnosis has increased. Nevertheless, cancer therapeutics that are available, such as surgery, chemotherapy, and radiotherapy are often associated with adverse side effects and significant morbidity $[1,2)$.

Incorporating complementary and alternative therapies into conventional cancer treatment could potentially reduce the side effects 
observed. Plant and spices used in traditional medicine are one of the main sources in the discovery and development of prophylactic and chemopreventive drugs. They have been known to have valuable properties ranging from antioxidant, anti-bacterial, anti-inflammatory, hepatoprotective, and anti-carcinogenic activities (3).

Vernonia amygdalina (VA), for example, is a plant used in African traditional medicine and has been studied widely in Africa (4). Vernonia amygdalina or "bitter leaf", as it is commonly known because of its bitter taste, is native to Nigeria. It can also be found in parts of Asia like Malaysia and Singapore (5). Leaf extracts of VA has been found to possess anti-oxidant, antibacterial, anti-inflammatory, anti-parasitic, and anti-cancer activities (3). The anti-cancer property of $V A$ was shown firstly in the human carcinoma of the nasopharynx by Kupchan et al in 1969 using a chloroform leaf extract of the plant (6). Phenolic compounds, sesquiterpene lactones, edotides, flavonoids, and saponins have been labeled as components that contribute to anti-cancer activity in $V A(3)$.

This systematic review aims to investigate the evidence of the in vitro anti-cancer effects of VA leaf extract and to determine whether it can be used as an effective alternative in cancer therapy.

\section{METHODS}

The search strategy for this systematic review complied under the guidelines of PRISMA (Preferred Reporting Items for Systematic Reviews and Meta-Analysis). Five electronic databases namely Scopus, Science Direct, PubMed, Springer, and Directory of Open Access Journals (DOAJ), were searched for relevant articles. Research articles regarding the anti-cancer activity of the VA leaf extract were reviewed for selection. Keywords used to identify appropriate articles were "Vermonia amygdalina", "cancer" or "anti-cancer". Experimental studies identified were limited to articles in the English language published from the $1^{\text {st }}$ of January 2000 to the $14^{\text {th }}$ of November 2018. Reviews and unpublished studies were not included. Articles were chosen for full-text reviewal based on the following criteria: Experiments investigating an in vitro study of human-derived cancer cells; Experiments using the VA leaf extract as a therapeutic agent (treatment); and experimental assays in the study can be used to interpret anticancer activity.
Searches were also aided by scanning bibliographies of articles. Articles undergoing fulltext reviewal were conducted independently by two reviewers. Figure 1 shows the flow of screening and selection of relevant articles using PRISMA. Data from the articles were extracted by summarizing each article using tables and written descriptions.
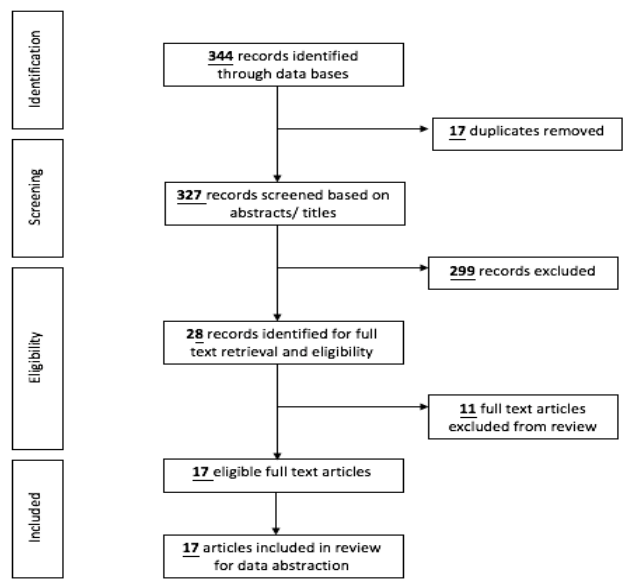

Figure 1: Flow diagram of the literature search strategy, which shows the trend of screening and choosing articles

\section{RESULTS}

A total of 344 articles were identified. 17 articles were found to be duplicated studies and 28 articles were identified after screening titles and abstracts. After further evaluation of the eligibility of full-text articles following the selection criteria, only 17 articles were included for the final review. The stages and results of the selection are presented in Figure 1. The findings of this study are further elaborated in subsequent sections, while brief summaries of all the articles are presented in Table 1 and Table 2.

A total of 9 different cancer cell lines were included in this review. The MCF-7 breast cancer cell line was used in the majority of the studies included in this review (Figure 2). A lot of data and information on the MCF-7 cell line have been published, which contributes to the fact that most studies in this review used this cell line.

Overall, the majority of studies included in this review used solvents such as deionized water, methanol, and ethanol in the preparation of the leaf extracts. Other less commonly used solvents included hexane, chloroform, butanol, ethyl acetate, and dichloromethane (Table 7). The label 'other' in table 7 refers to studies that extracted a particular compound from the VA leaf. For example, vernodalinol (7) and vernolide 
Table 1: Summary of anti-cancer activities of Vernonia amygdalina in human-derived cancer cells

\begin{tabular}{|c|c|c|c|}
\hline \multirow{2}{*}{ Ref. } & \multirow{2}{*}{ Cancer type and cell line used } & \multicolumn{2}{|c|}{ Method } \\
\hline & & Extract used & $\begin{array}{c}\text { Assays used } \\
\end{array}$ \\
\hline $\begin{array}{l}\text { Oyugi } \\
\text { et al(9). }\end{array}$ & Human breast adenocarcinoma (MCF-7) & $\begin{array}{l}\text { Aqueous extract was made by soaking dried leaves in } \\
\text { ddH }{ }_{2} \mathrm{O} \text { mixed, filtered and lyophilized. Using liquid-liquid } \\
\text { extraction Hexane, chloroform and butanol extracts were } \\
\text { evaporated under reduced pressure and lyophilized. } \\
\text { Using silica gel method, hexane, chloroform, ethyl } \\
\text { acetate, butanol, and methanol extracts were made. }\end{array}$ & $\begin{array}{l}\text { Cell proliferation studies were done by viewing cells } \\
\text { under the microscope and counting cells with a } \\
\text { hemocytometer after treatment. } \\
\text { Used Thymidine incorporation assay to determine } \\
\text { DNA synthesis. }\end{array}$ \\
\hline Iweala et al(10). & $\begin{array}{l}\text { Human myeloid leukemia (HL-60), } \\
\text { hepatocellular carcinoma (SMMC-7721), } \\
\text { lung carcinoma (A-549), breast } \\
\text { adenocarcinoma (MCF-7), and colon } \\
\text { cancer (SW480). }\end{array}$ & $\begin{array}{l}\text { Powdered leaves were successively extracted with } \\
\text { hexane, dichloromethane, ethanol and water (aqueous) } \\
\text { using reflux apparatus, filtered and evaporated under } \\
\text { reduced pressure while the water extract was lyophilized. }\end{array}$ & $\begin{array}{l}\text { Cell proliferation studies were done using a modified } \\
\text { MTT assay: MTS assay. }\end{array}$ \\
\hline $\begin{array}{l}\text { Lifiani } \\
\text { et al(11). }\end{array}$ & $\begin{array}{l}\text { Human breast adenocarcinoma resistant } \\
\text { to doxorubicin and normal human breast } \\
\text { adenocarcinoma (T47D) }\end{array}$ & $\begin{array}{l}\text { Using the maceration method, dried leaves were } \\
\text { extracted using hexane, ethyl acetate, and ethanol. } \\
\text { transferred to Rotavapor and lyophilized. }\end{array}$ & $\begin{array}{l}\text { Cell proliferation studies were done using MTT assay. } \\
\text { Cell cycle and apoptosis analysis were done using } \\
\text { the flow cytometry method. }\end{array}$ \\
\hline
\end{tabular}

Table 2: Summary of anti-cancer activities of Vernonia amygdalina in human-derived cancer cells

\begin{tabular}{|c|c|c|c|c|}
\hline \multirow{2}{*}{ Ref. } & \multirow{2}{*}{$\begin{array}{c}\text { Cancer type and cell line } \\
\text { used }\end{array}$} & \multicolumn{2}{|c|}{ Methods } & \multirow{2}{*}{ Main Results } \\
\hline & & Extracts used & $\begin{array}{l}\text { Assays used } \\
\end{array}$ & \\
\hline $\begin{array}{l}\text { Opata } \\
\& \\
\text { Izevbigie } \\
\text { (12). }\end{array}$ & $\begin{array}{l}\text { Human breast } \\
\text { adenocarcinoma (MCF-7) }\end{array}$ & $\begin{array}{l}\text { Aqueous extract was made by soaking dried } \\
\text { leaves in } \mathrm{dH}_{2} \mathrm{O} \text {, macerated, filtered, and } \\
\text { lyophilized. }\end{array}$ & $\begin{array}{l}\text { Cell proliferation studies were done } \\
\text { by viewing cells under the } \\
\text { microscope and counting cells with a } \\
\text { hemocytometer after treatment. } \\
\text { Thymidine incorporation assay used } \\
\text { to determine DNA synthesis. } \\
\text { The effect of extract on cell } \\
\text { permeability and efflux was } \\
\text { evaluated using }\left[{ }^{3} \mathrm{H}\right] \text { thymidine } \\
\text { challenge and measuring } \\
\text { radioactivity. }\end{array}$ & $\begin{array}{l}10 \mu \mathrm{g} / \mathrm{ml} \text { of extract inhibited growth by } 54 \% \text { for cells in } \\
\text { serum-free medium whereas it was only } 7 \% \text { in serum } \\
\text { medium. } 97 \% \text { DNA synthesis was inhibited when treated } \\
\text { with } 1000 \mu \mathrm{g} / \mathrm{ml} \text { of extract (similar in both media). }\left[{ }^{3} \mathrm{H}\right] \\
\text { thymidine uptake decreased from } 113,633 \text { to } 3708 \text { counts } \\
\text { per minute when exposed to } 100 \mu \mathrm{g} / \mathrm{ml} \text { of extract. Using } \\
\text { cell counts, the extract had } \mathrm{IC}_{50} \text { value of } 218 \mu \mathrm{g} / \mathrm{ml} \text {. } \\
\text { (Treated for } 24 \text { hours). }\end{array}$ \\
\hline $\begin{array}{l}\text { Rohin } \\
\text { et al(13). }\end{array}$ & $\begin{array}{l}\text { Human glioblastoma brain } \\
\text { cancer (U-87) }\end{array}$ & $\begin{array}{l}\text { Dried leaves were ground to a fine powder } \\
\text { followed by a sequential soaking process } \\
\text { using ethanol, methanol, and ethyl acetate. } \\
\text { Extracts were then filtered and concentrated. }\end{array}$ & $\begin{array}{l}\text { Cell proliferation studies were done } \\
\text { using MTT assay. }\end{array}$ & $\begin{array}{l}\text { Only the ethyl acetate extract was shown to be cytotoxic } \\
\text { towards the cells with an IC } \mathrm{C}_{50} \text { value of } 18.80 \pm 1.11 \mu \mathrm{g} / \mathrm{ml} \text {. } \\
\text { It reaches } \mathrm{IC}_{50} \text { after } 72 \text { hours. }\end{array}$ \\
\hline $\begin{array}{l}\text { Rohin } \\
\text { et al(14). }\end{array}$ & $\begin{array}{l}\text { Human glioblastoma brain } \\
\text { cancer (U-87) }\end{array}$ & $\begin{array}{l}\text { Dried leaves were ground to a fine powder } \\
\text { followed by a sequential soaking process } \\
\text { using ethanol, methanol, and ethyl acetate. } \\
\text { Extracts were then filtered and concentrated. }\end{array}$ & $\begin{array}{l}\text { Morphological analysis was done by } \\
\text { examining the treated cells under a } \\
\text { light microscope. Cell proliferation } \\
\text { studies were done using MTT assay }\end{array}$ & $\begin{array}{l}\text { Only the ethyl acetate extract was shown to be cytotoxic } \\
\text { towards the cells with an IC } \mathrm{I}_{50} \text { value of } 48.0 \pm 26.72 \mu \mathrm{g} / \mathrm{ml} \text {. } \\
\text { Morphological features also showed early stages of } \\
\text { apoptosis and cell shrinkage. It reaches } \mathrm{IC}_{50} \text { after } 72 \\
\text { hours. }\end{array}$ \\
\hline
\end{tabular}

Trop J Pharm Res, August 2020; 19(8): 1777 
Table 2: Summary of anti-cancer activities of Vernonia amygdalina in human-derived cancer cells (continued)

\begin{tabular}{|c|c|c|c|c|}
\hline \multirow{2}{*}{ Ref } & \multirow{2}{*}{$\begin{array}{c}\text { Cancer type and cell line } \\
\text { used }\end{array}$} & \multicolumn{2}{|c|}{ Methods } & \multirow{2}{*}{ Main Results } \\
\hline & & $\begin{array}{l}\text { Extracts used } \\
\end{array}$ & Assays used & \\
\hline $\begin{array}{l}\text { Izevbigie } \\
\text { (15). }\end{array}$ & $\begin{array}{l}\text { Human breast } \\
\text { adenocarcinoma (MCF-7) }\end{array}$ & $\begin{array}{l}\text { Aqueous extract was made by soaking } \\
\text { dried leaves in } \mathrm{dH}_{2} \mathrm{O} \text {, macerated, } \\
\text { filtered, and lyophilized. Using reverse- } \\
\text { phase chromatography (RPC) and } \\
\text { preparative reverse-phase } \\
\text { chromatography (PRPC), the extract } \\
\text { was further divided into } \\
\text { chromatographic fractions. }\end{array}$ & $\begin{array}{l}\text { Thymidine incorporation assay used } \\
\text { to determine DNA synthesis for } \\
\text { treated cells with and without serum. } \\
\text { Cell viability studies were done using } \\
\text { the MTT assay and trypan blue } \\
\text { exclusion assay. }\end{array}$ & $\begin{array}{l}\text { Concentration of extract needed to get IC } 50 \text { was } \\
5.68 \pm 0.2 \mu \mathrm{g} / \mathrm{ml} \text {. At } 200 \mu \mathrm{g} / \mathrm{ml} \text {, DNA synthesis } \\
\text { was completely inhibited in the absence and } \\
\text { presence of serum. RPC fractions of extract } \\
\text { (edotides) showed DNA inhibitory effects at } 100 \\
\mathrm{ng} / \mathrm{ml} \text {. (treated for } 48 \text { hours). }\end{array}$ \\
\hline $\begin{array}{l}\text { Luo et al } \\
\text { (7). }\end{array}$ & $\begin{array}{l}\text { Human breast } \\
\text { adenocarcinoma (MCF-7) }\end{array}$ & $\begin{array}{l}\text { Dried Leaves were extracted with } 85 \% \\
\text { ethanol separated into } 4 \text { fractions of } \\
\text { hexane, chloroform and butanol extracts } \\
\text { by liquid-liquid extraction technique. } \\
\text { Vernodalinol was separated from the } \\
\text { butanol extract by column } \\
\text { chromatography. }\end{array}$ & $\begin{array}{l}\text { Thymidine incorporation assay used } \\
\text { to determine DNA synthesis. }\end{array}$ & $\begin{array}{l}50 \mu \mathrm{g} / \mathrm{ml} \text { of vernodalinol inhibited } 40 \% \text { of DNA } \\
\text { synthesis and has modest anti-cancer activity } \\
\text { (treated for } 22 \text { hours). }\end{array}$ \\
\hline $\begin{array}{l}\text { Adeoye } \\
\text { et al(16). }\end{array}$ & $\begin{array}{l}\text { Human colorectal } \\
\text { adenocarcinoma (HT29) }\end{array}$ & $\begin{array}{l}\text { Methanolic extract was made by } \\
\text { dissolved powdered leaves into } \\
\text { methanol, macerated, and evaporated. }\end{array}$ & $\begin{array}{l}\text { Cell viability studies were done using } \\
\text { the MTT assay. }\end{array}$ & $\begin{array}{l}\text { At } 200 \mu \mathrm{g} / \mathrm{ml} \text { extract concentration, there was } \\
50 \% \text { cell inhibition when treated for } 48 \text { hours. }\end{array}$ \\
\hline $\begin{array}{l}\text { Yedjou } \\
\text { et al(17). }\end{array}$ & $\begin{array}{l}\text { Human lung carcinoma (A- } \\
549) \text { and human prostate } \\
\text { cancer (PC-3) }\end{array}$ & $\begin{array}{l}\text { Methanolic extract was made by heating } \\
\text { the dried leaves and methanol together, } \\
\text { filtering with cheesecloth and } \\
\text { evaporated under reduced pressure. }\end{array}$ & $\begin{array}{l}\text { Examined cellular morphology, } \\
\text { damage, viability, and apoptosis or } \\
\text { necrosis using cellular double } \\
\text { staining technique with Acridine } \\
\text { orange (AO) and Propidium iodide } \\
\text { (PI), and examined under fluorescent } \\
\text { microscope. }\end{array}$ & $\begin{array}{l}\text { Strong dose-response relationship with regard } \\
\text { to treatment. Doses were } 125,250 \text { and } 500 \\
\mu \mathrm{g} / \mathrm{ml} \text { (treated for } 48 \text { hours). There was an } \\
\text { increase in the percentage of dead cells } \\
\text { compared to the control in both types of cancer } \\
\text { cells. }\end{array}$ \\
\hline $\begin{array}{l}\text { Wong } \\
\text { et al [18]. }\end{array}$ & $\begin{array}{l}\text { Human breast } \\
\text { adenocarcinoma (MCF-7 and } \\
\text { MDA-MB-231) }\end{array}$ & $\begin{array}{l}\text { Ethanolic extract was made by soaking } \\
\text { fresh leaves in } 80 \% \text { ethanol, blending } \\
\text { and filtering, the filtrate was then } \\
\text { evaporated under reduced pressure and } \\
\text { lyophilized. }\end{array}$ & $\begin{array}{l}\text { Cell proliferation studies were done } \\
\text { using the MTT assay. The effect of } \\
\text { extract on cell cycle was done using } \\
\text { flow cytometric analysis. Apoptotic } \\
\text { and/or necrotic cells were } \\
\text { differentiated using the Annexin V- } \\
\text { FITC/PI assay. }\end{array}$ & $\begin{array}{l}\text { The IC } 50 \text { values at } 24,48 \text { and } 72 \text { hours for MCF- } \\
7 \text { cells were } 100,66 \text { and } 56 \mu \mathrm{g} / \mathrm{ml} \text { respectively. } \\
\text { The IC } 50 \text { values for MDA-MB-231 cells were } 83 \text {, } \\
53 \text {, and } 46 \mu \mathrm{g} / \mathrm{ml} \text { at } 24,48 \text { and } 72 \text { hours } \\
\text { respectively. The extract induced a G1/S cell } \\
\text { cycle arrest in MCF- } 7 \text { cells at } 24 \text { hours and } 48 \\
\text { hours after which cells began to undergo } \\
\text { apoptosis at } 72 \text { hours at the highest dose (100 } \\
\mu \mathrm{g} / \mathrm{ml}) . \text { However, no cell cycle arrest was } \\
\text { observed in MDA-MB- } 231 \text { cells. Apoptosis was } \\
\text { observed at } 72 \text { hours when treated with the } \\
\text { highest dose. }\end{array}$ \\
\hline
\end{tabular}


Table 2: Summary of anti-cancer activities of Vernonia amygdalina in human-derived cancer cells (continued)

\begin{tabular}{|c|c|c|c|c|}
\hline \multirow{2}{*}{ Ref } & \multirow{2}{*}{$\begin{array}{l}\text { Cancer type and cell } \\
\text { line used }\end{array}$} & \multicolumn{2}{|c|}{ Methods } & \multirow{2}{*}{ Main Results } \\
\hline & & Extracts used & Assays used & \\
\hline $\begin{array}{l}\text { Sinisi } \\
\text { et al(8) }\end{array}$ & $\begin{array}{l}\text { Human Prostate } \\
\text { Cancer (DU145) }\end{array}$ & $\begin{array}{l}\text { Methanolic extract was made by } \\
\text { macerating dried leaf powder in } \\
\text { methanol, filtered and evaporated. } \\
\text { Using high-performance liquid } \\
\text { chromatography (HLPC) the extracted } \\
\text { was separated to isolate Vernolide and } \\
\text { other compounds. }\end{array}$ & $\begin{array}{l}\text { Cell proliferation studies were done using the } \\
\text { MTT assay. The effect of vernolide on cell } \\
\text { cycle was done using flow cytometric } \\
\text { analysis. }\end{array}$ & $\begin{array}{l}\text { The } \mathrm{IC}_{50} \text { value of vernolide is } 40.1 \pm 4.3 \mu \mathrm{M} \text {. Vernolide } \\
\text { also induced cell cycle arrest at } \mathrm{G}_{2} \mathrm{M} \text { and } \mathrm{S} \text { phases. For } \\
\text { the MTT assay, cells were treated for } 48 \text { hours whereas } \\
\text { cells were treated for } 24 \text { hours for the flow cytometry } \\
\text { analysis. }\end{array}$ \\
\hline $\begin{array}{l}\text { Yedjou } \\
\text { et al(19). }\end{array}$ & $\begin{array}{l}\text { Human breast } \\
\text { adenocarcinoma } \\
\text { (MCF-7) }\end{array}$ & $\begin{array}{l}\text { Aqueous extract was made by soaking } \\
\text { dried leaves in } \mathrm{dH}_{2} \mathrm{O} \text {, macerated, } \\
\text { filtered and lyophilized. }\end{array}$ & $\begin{array}{l}\text { Cell proliferation studies were done using the } \\
\text { MTT assay. The comet/ genotoxicity assay } \\
\text { was done to observe DNA damage by the } \\
\text { extract. }\end{array}$ & $\begin{array}{l}\text { The extract caused moderate cytotoxicity to MCF- } 7 \text { cells } \\
\text { and did not reach } \mathrm{IC}_{50} \text { even at highest dose of } 2 \mathrm{mg} / \mathrm{ml} \text {. } \\
\text { The extract also caused minimal DNA damage in a dose- } \\
\text { dependent fashion. }\end{array}$ \\
\hline $\begin{array}{l}\text { Cameron } \\
\text { et al(20). }\end{array}$ & $\begin{array}{l}\text { Human prostate } \\
\text { cancer (PC-3) }\end{array}$ & $\begin{array}{l}\text { Aqueous extract was made by soaking } \\
\text { dried leaves in } \mathrm{dH}_{2} \mathrm{O} \text {, squeezed by } \\
\text { hand, filtered, and lyophilized. }\end{array}$ & $\begin{array}{l}\text { Thymidine incorporation assay used to } \\
\text { determine DNA synthesis. }\end{array}$ & $\begin{array}{l}\text { The extract inhibited DNA synthesis in a concentration- } \\
\text { dependent fashion. DNA synthesis was inhibited by } 73 \% \\
\text { when treated with } 1 \mathrm{mg} / \mathrm{ml} \text { extract. }\end{array}$ \\
\hline $\begin{array}{l}\text { Johnson } \\
\text { et al(21). }\end{array}$ & $\begin{array}{l}\text { Human prostate } \\
\text { cancer (PC-3) }\end{array}$ & $\begin{array}{l}\text { Methanol extract was made by heating } \\
\text { the dried leaves and methanol together, } \\
\text { filtering with cheesecloth and } \\
\text { evaporated under reduced pressure. }\end{array}$ & $\begin{array}{l}\text { Cell viability was determined using a trypan } \\
\text { blue dye exclusion assay and MTT assay. } \\
\text { The comet/genotoxicity assay was done to } \\
\text { observed DNA damage caused by the } \\
\text { extract. Apoptotic and/or necrotic cells were } \\
\text { differentiated using the Annexin V-FITC/PI } \\
\text { assay. A Lipid Peroxidation assay was done } \\
\text { to measure malondialdehyde (MDA). }\end{array}$ & $\begin{array}{l}\text { The IC } 50 \text { value of the extract was } 196.6 \mu \mathrm{g} / \mathrm{ml} \text { for } 48 \text { hours } \\
\text { of exposure. When observed morphologically, treated } \\
\text { cells showed significant cell damage at } 500 \mu \mathrm{g} / \mathrm{ml} \text {. This } \\
\text { was confirmed using the Annexin V-FITC/PI assay. The } \\
\text { extract gradually decreases MDA generation in cells } \\
\text { however there was a significant increase at the highest } \\
\text { does due to high level of cell death. The extract also } \\
\text { induced DNA damage and apoptosis as well as necrosis } \\
\text { in a dose-dependent fashion. }\end{array}$ \\
\hline $\begin{array}{l}\text { Gresham } \\
\text { et al(22). }\end{array}$ & $\begin{array}{l}\text { Human ductal } \\
\text { carcinoma (BT- 549) }\end{array}$ & $\begin{array}{l}\text { Aqueous extract was made by soaking } \\
\text { dried leaves in } \mathrm{dH}_{2} \mathrm{O} \text {, squeezed by } \\
\text { hand, filtered and lyophilized. }\end{array}$ & $\begin{array}{l}\text { Cell proliferation was determined by counting } \\
\text { cells with a hemocytometer. Thymidine } \\
\text { incorporation assay was used to determine } \\
\text { DNA synthesis. }\end{array}$ & $\begin{array}{l}\text { At } 1000 \mu \mathrm{g} / \mathrm{ml} \text {, the extract inhibited cell proliferation by } \\
50 \%(\mathrm{IC} 50) \text {. The extract also induced DNA damage in a } \\
\text { dose-dependent fashion. } 76 \% \text { of DNA synthesis was } \\
\text { inhibited at } 1000 \mu \mathrm{g} / \mathrm{ml} \text {. }\end{array}$ \\
\hline $\begin{array}{l}\text { Yedjou } \\
\text { et al(23). }\end{array}$ & $\begin{array}{l}\text { Human breast } \\
\text { carcinoma (MCF-7) }\end{array}$ & $\begin{array}{l}\text { Aqueous extract was made by soaking } \\
\text { dried leaves in } \mathrm{dH}_{2} \mathrm{O} \text {, crushed gently, } \\
\text { filtered, and lyophilized. }\end{array}$ & $\begin{array}{l}\text { Cell proliferation studies were done using } \\
\text { trypan blue exclusion test. The effect of } \\
\text { extract on apoptosis and necrosis was done } \\
\text { using flow cytometric analysis. Cellometer } \\
\text { Imaging used to confirm necrosis. }\end{array}$ & $\begin{array}{l}\text { The extract reduced cell viability in a time- and } \\
\text { concentration-dependent manners. } 1000 \mu \mathrm{g} / \mathrm{ml} \text { of extract } \\
\text { for } 48 \text { hours reduced viable cell counts to } 49 \% \text {. The } \\
\text { extract also increased necrosis in cells. }\end{array}$ \\
\hline
\end{tabular}




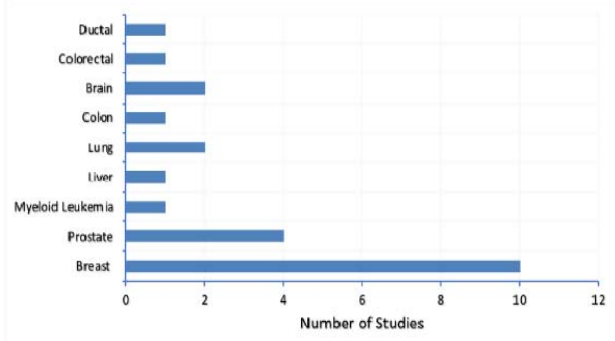

Figure 2: Type of cancer cells used in the studies included in this review. Only 3 studies included more than one type of different cell lines in an individual experiment

(8). The rest of the extracts used were crude extracts. The total number exceeds 17 because seven studies used different extract as the treatment in the same individual experiment.

\section{DISCUSSION}

\section{Potency of Vernonia amygdalina leaf extracts}

Based on the half maximal inhibitory concentration $\left(\mathrm{IC}_{50}\right)$ values and overall cell proliferation, the most potent extract in all studies was the dichloromethane extract on human myeloid leukemia (HL-60), with an $\mathrm{IC}_{50}$ value of $5.58 \mu \mathrm{g} / \mathrm{mL}$. The dichloromethane extract was also found to show strong cytotoxicity in other cell lines when compared with other types of extracts (10). However, only a single study in this review used dichloromethane extract. Thus, it was difficult to gauge its replicability.

Two studies extracted specific compounds from the VA leaf, one being vernodalinol (7) and the other, vernolide (8). $50 \mu \mathrm{g} / \mathrm{mL}$ of vernodalinol was able to inhibit $40 \%$ of DNA synthesis (7).Nevertheless, no MTT assay was done. Thus, the $I C_{50}$ value of vernodalinol could not be determined. In contrast, the $\mathrm{IC}_{50}$ value of vernolide was $40.1 \pm 4.3 \mu \mathrm{M}$, and it arrested the cell cycle at the $S$ phase, thus inhibiting DNA synthesis (8).

In another study, Izevbigie found that the aqueous extract of $V A$ was able to elicit cytotoxic activity in MCF-7 cells with an $\mathrm{IC}_{50}$ value of 5.68 $\pm 0.2 \mu \mathrm{g} / \mathrm{mL}$ (15). However, this $\mathrm{IC}_{50}$ value is not consistent with the results found in other studies. This could be attributed to variation in potency between different $V A$ batches, which leads to different levels of anti-cancer activity.

The most effective and consistent extract was the ethyl acetate extract. In all the studies that included ethyl acetate extract, strong activity against cancer cell proliferation was consistently detected.

Table 7: Different VA leaf extracts used in the selected studies in this review

\begin{tabular}{lc}
\hline Type of extract used & Number of studies \\
\hline Ethanol & 5 \\
Aqueous & 8 \\
Hexane & 3 \\
Chloroform & 1 \\
Butanol & 1 \\
Ethyl Acetate & 4 \\
Methanol & 6 \\
Dichloromethane & 1 \\
Other & 2 \\
\hline
\end{tabular}

\section{Experimental assays to determine anti-cancer activity}

\section{Cell viability tests}

3-(4,5-dimethylthiazol-2-yl)-2,5-diphenyl tetrazolium bromide (MTT) assay was the most commonly used assay to observe cytotoxicity after the cell lines were treated with the extract. This tetrazolium salt (MTT), which is blue in color, will be reduced and to purple formazan in cells that contain functioning mitochondria. Dead cells would not be able to reduce MTT. Therefore, by measuring the formation of formazan using a spectrophotometer, the percentage of cell viability can be calculated by comparing the readings of treated cells and untreated cells. The reduction in the production of formazan reflects a decrease in cell proliferation.

The trypan blue exclusion assay was also used in some studies to calculate cell viability. Only non-viable cells are permeable to the trypan blue dye, thus dying cells would be dyed blue. The number of non-viable and viable cells can be counted using a hemocytometer under a light microscope. As a preliminary finding, the extracts can be interpreted as having anti-cancer activity if the percentage of non-viable cells are higher in samples that undergo treatment as compared to control samples. Vernonia amygdalina showed inhibitory effects on the cancer cell proliferation. Cancer cell viability decreases as the VA extract concentration increases $(21,23)$.

However, before the trypan blue exclusion assay, the cells were treated with trypsin in most studies. This might play a part in affecting cell viability as trypsin compromises cell membrane integrity which then causes the treated cells to be more susceptible to the VA treatment. 
Non-conventional techniques were also used in some studies. Yedjou et al showed a novel cellular staining technique that used double staining of acridine orange (AO) and propidium iodide $(\mathrm{Pl})$. Acridine orange is permeable to both live and dead cells and emits green fluorescence. In contrast, $\mathrm{PI}$ is permeable only to dead cells and emits red fluorescence. By reading the red fluorescence (dead cells) versus green fluorescence (live cells) under a fluorescent microscope, cell viability can be assessed. There is an increased proportion of red fluorescence as $V A$ concentration increases (24).

In the 17 studies, it was observed that VA extracts had a significant effect on cell viability in various cancer cell lines. Overall, using the cell viability assays described above, the VA extract treatment decreased cell viability in a concentration- and time-dependent fashion (23). This can be interpreted as an anti-cancer activity as there is a decrease in cancer cell proliferation.

\section{Evaluation of DNA synthesis/DNA damage}

The thymidine incorporation assay has been used to determine DNA synthesis in the studies of this review. The radioactive nucleoside, $3 \mathrm{H}$ thymidine, is incorporated into new DNA strands during mitosis. Therefore, by measuring radioactivity in the DNA, it is possible to estimate DNA synthesis (25). If a decrease in DNA synthesis is detected, it reflects the poor proliferation of cells, thus it can be interpreted as an anti-cancer activity (22).

DNA damage, can be assessed by using singlecell gel electrophoresis (Comet Assay). DNA fragments are resolved in agarose gel using an electric current. Based on the finding of a study, a higher intensity of fragment migration would signify high DNA damage. In contrast, no migration would suggest no DNA damage (21).

Vernonia amygdalina extracts exhibit minimal DNA damage and inhibit DNA synthesis in a concentration-dependent manner. In general, it is reported that agents that cause slight DNA damage are good candidates for cancer therapy (19). However, if it causes sustained DNA damage and does not induce cell death it could potentially be a carcinogen (19). Based on this principle, VA can be still considered as a candidate for cancer therapy as it induces cell death.

\section{Cell cycle and apoptosis/necrosis analysis}

The flow cytometric analysis and Annexin V
FITC/PI assays were used to determine the effect of $V A$ extract on cell cycle, and to determine whether it exhibit anti-cancer activity by inducing apoptosis or necrosis. To study if VA could lead to cell cycle arrest, the cells were stained with propidium iodide (PI). Propidium iodide stains the cellular DNA of cells that have a compromised cell membrane. Following that, flow cytometry is used to analyze the phase of the cell cycle, based on the amount of DNA present in the cell (11). Subsequently, the Annexin V FITC/PI assay used (with Annexin V and $\mathrm{PI}$ as labels) to distinguish between apoptotic or necrotic cells. Annexin V (AV) binds to the plasma membrane of cells undergoing apoptosis, while PI stains cellular DNA of cells with a damaged cell membrane. Using flow cytometry, stages of the cell cycle can be determined. Early apoptotic cells would be positive for AV and negative for PI, late apoptotic or necrotic cells would be positive for both, whereas cells undergoing necrosis would be positive for PI but negative for AV (23).

In all the studies that used the Annexin V FITC/PI assay, the VA extract was found to induce apoptosis in cancer cells in a concentrationdependent manner, regardless of the cancer cell line. Furthermore, at a higher concentration, the $V A$ extract induced necrosis as well. Research showed that the VA most likely caused apoptotic or necrotic cell death by inducing loss of membrane integrity (24).

However, it is important to note that $V A$ extracts arrest different stages of the cell cycle in different cancer cells lines. In DU145 cells, VA caused cell cycle arrest at the $S$ phase, when DNA replication occurs (8). T47D cells were held in the G0-G1 phase (11). Another study found that $V A$ induced G1/S cell cycle arrest in MCF-7 cells but did not cause cell cycle arrest in MDA-MB231 cells (18). This further highlights the anticancer property of $V A$, in which it has different regulations on cell cycle progression for different cancer cell lines but eventually causes cell death.

\section{Anti-cancer activity}

Vernonia amygdalina is rich in biologically-active compounds such as antioxidants and polyphenols. These compounds are known to be protective against tumors (13). Oxidative stress often causes chronic inflammation, which might lead to cancer. The antioxidant compounds in VA are able to defend the body by scavenging free radicals and thus normalizing the oxidative state(13). This proves to be helpful in the prevention of cancer. Vernonia amygdalina also showed a broad spectrum of cytotoxicity as it 
was able to elicit anti-cancer effects across a number of different cancer cell lines (18).

However, the quantity and quality of the biologically active compounds in VA could differ with location, seasonal and propagation conditions, age at harvest, and storage conditions. Thus, the potency of anti-cancer activity may vary between batches of $V A$. The spectroscopic and chromatographic techniques described by Oyugi and colleagues can be used to monitor the quality of $V A(9)$.

The exact anti-cancer mechanism exerted by VA has been researched heavily upon. Evidence shows that $V A$ retards cancer cell proliferation in a concentration- and time-dependent manner. The retardation took place via DNA synthesis inhibition and DNA damage. This can be interpreted as anti-cancer activity as DNA synthesis is required for cell growth. It has also been observed that DNA damage increases proportionately with increasing doses of $V A$. Vernonia amygdalina also modulates biotransformation enzymes which cause the formation of ion channels that leads to depolarization of the cell and eventually cell death (18). Vernonia amygdalina has also been found to inhibit mitogen-activated protein kinases (MAPKs), which are a key regulation point of tumor growth in MCF-7 cells (15). Another anticancer mechanism of VA lies within its ability to alter cell permeability and inhibit the expression of ER- $\alpha$, a receptor which is expressed in $70 \%$ of breast cancer cells(18).

Vernonia amygdalina has also been shown to be non-toxic to normal cells. For example, normal mouse fibroblasts showed negative results for antiproliferative effect when treated with $V A$ extract (14). In another study, VA increased cell proliferation in vascular smooth muscle cells without showing any cytotoxic effects (16). Consumption of VA at 400 to $800 \mathrm{mg} / \mathrm{kg}$ of body weight did not appear to lead to any cytotoxic effects in albino rats (19). Despite that, a good question still to be addressed is to see whether VA causes DNA damage to normal cells. Vernonia aygdalina might not be toxic to normal cells, but if it causes sustained DNA damage, it might increase the risk of developing a mutation that might lead to cancer.

Vernonia amygdalina also exhibited synergism with doxorubicin, a common used chemotherapy drug (18). Thus, this opens up the possibility of the use of $V A$ in conjunction with other chemotherapy drugs. In addition, VA acts as a chemosensitizer. It has the ability to decrease the multi-drug resistance (MDR) phenotype in cancer cells (18). Multi-drug resistance often results in rapid clearance of anticancer drugs from cells before they can elicit their full therapeutic actions, thereby rendering the anticancer drug to be ineffective. Therefore, by acting as a chemosensitizer, $V A$ is able to improve the efficacy of chemotherapy drugs.

In this review, the molecular mechanisms of the anti-cancer activity of $V A$ were reported in a few of the studies. Wong et al. showed that VA extract induced cell cycle arrest in MCF-7 cells by modulating the expression of cell cycle regulators (18). Using Western blot analysis, VA was shown to give rise to p53 activation, a tumor suppressor gene that plays a crucial role in regulating the cell cycle (18). The increased p53 expression was correlated with the increase of $\mathrm{p} 21$, a transcriptional target gene of $\mathrm{p} 53$. On the other hand, G1 cell cycle regulators were suppressed after VA treatment. However, when p53 was inhibited using a wild type inhibitor, the $V A$-induced cell arrest persisted. This suggests that the VA might induce cell cycle arrest through a p53-independent pathway (18).

In addition, VA was postulated to induce apoptosis via the activation of the expression of initiator caspases and effector caspases, which play a role in regulating apoptosis. A general caspase inhibitor was able to reduce the number of VA-induced apoptotic cells, thereby resulting in VA induced caspase-dependent apoptosis (18). Cameron et al also found that VA extract was able to activate mitogen-activated protein kinases (MAPKs), decrease NF-KB activity and activate $c-M y c$. Evidence suggested that MAPKs, NF-kB, and c-Myc are involved in tumor cell proliferation (20). Another study also showed that vernolide in VA inhibited the pro-inflammatory transcription factors NF- $\mathrm{KB}$, and STAT3. This led to higher oxidative stress, which subsequently induced cytotoxicity [8].

\section{CONCLUDING REMARKS}

Vernonia amygdalina shows potential to be used as a cancer therapeutics. However, more research is needed to see the effects of VA on normal cells. Vernonia amygdalina elicits an array of anti-cancer activity in different cancer cell lines by causing apoptosis and cell cycle arrest through up-regulation or down-regulation of the genes involved. Numerous in vitro studies supported this claim. Studies included in this review also revealed that $V A$ inhibits inflammatory transcription factors in a few types of cancer, showing a possible connection between inflammation and cancer progression. Thus, further studies should also be conducted to 
explore the molecular mechanism of $V A$ in other cancer cell lines in greater depth. Furthermore, this review highlighted the discrepancies in the potency of VA extract between different studies due to the difference in potency between batches. Future research should focus on determining the activity markers of $V A$, and the potency level in different batches of VA. By expanding the knowledge on the properties of $V A$, it will pave the way forward for $V A$ to be recognized as a standard anti-cancer therapy.

\section{DECLARATIONS}

\section{Acknowledgement}

The authors would like to acknowledge the funding by University Sains Malaysia Bridging Grant no. 304/CIPPT/6316487 and IPPT KPI Intensive (2019).

\section{Conflict of interest}

No conflict of interest is associated with this work.

\section{Contribution of authors}

We declare that this work was done by the authors named in this article and all liabilities pertaining to claims relating to the content of this article will be borne by the authors.

\section{Open Access}

This is an Open Access article that uses a funding model which does not charge readers or their institutions for access and distributed under the terms of the Creative Commons Attribution License (http://creativecommons.org/licenses/by/ 4.0) and the Budapest Open Access Initiative (http://www.budapestopenaccessinitiative.org/rea d), which permit unrestricted use, distribution, and reproduction in any medium, provided the original work is properly credited.

\section{REFERENCES}

1. Henley SJ, Singh SD, King J, Wilson RJ, O'Neil ME, Ryerson $A B$. Invasive cancer incidence and survival United States, 2013. Vol. 66, Morbidity and Mortality Weekly Report. Department of Health and Human Services; 2017. p. 69-75.

2. Lewis J. Anti-cancer effects of aloe-emodin: a systematic review. J Clin Transl Res. 2017;

3. Farombi EO, Owoeye $O$. Antioxidative and chemopreventive properties of Vernonia amygdalina and Garcinia biflavonoid. Int J Environ Res Public
Health [Internet]. 2011 [cited 2019 Aug 27];8(6):253355. Available from: http://www.ncbi.nlm.nih.gov/pubmed/21776245

4. Ijeh II, Ejike CECC. Current perspectives on the medicinal potentials of Vernonia amygdalina Del. J Med Plants Res [Internet]. 2011 [cited 2019 Dec 13];5(7):1051-61. Available from: http://www.academicjournals.org/JMPR

5. Moga K. Antioxidant and antiproliferative activities of plant derived extracts against cervical and prostate cancer cell lines. Jomo Kenyatta University of Agriculture and technology; 2018.

6. Morris Kupchan S, Hemingway RJ, Karim A, Werner D. Tumor Inhibitors. XLVII. Vernodalin and Vernomygdin, Two New Cytotoxic Sesquiterpene Lactones from Vernonia amygdalina Del. J Org Chem. 1969;34(12):3908-11.

7. Luo $X$, Jiang $Y$, Fronczek FR, Lin C, Izevbigie EB, Lee $K S$. Isolation and structure determination of a sesquiterpene lactone (vernodalinol) from Vernonia amygdalina extracts. Pharm Biol. 2011;49(5):464-70.

8. Sinisi A, Millán E, Abay SM, Habluetzel A, Appendino G, Muñoz E, et al. Poly-Electrophilic Sesquiterpene Lactones from Vernonia amygdalina: New Members and Differences in Their Mechanism of Thiol Trapping and in Bioactivity. J Nat Prod. 2015;78(7):1618-23.

9. Oyugi DA, Luo X, Lee KS, Hill B, Izevbigie EB. Activity Markers of the Anti-Breast Carcinoma Cell Growth Fractions of Vernonia amygdalina Extracts. Exp Biol Med [Internet]. 2009;234(4):410-7. Available from: http://journals.sagepub.com/doi/10.3181/0811-RM-325

10. Iweala EEJ, Liu F-F, Cheng R-R, Li Y, Omonhinmin CA, Zhang $Y$-J. Anti-Cancer and Free Radical Scavenging Activity of Some Nigerian Food Plants in vitro. Int $\mathrm{J}$ Cancer Res [Internet]. 2015 Jan 1;11(1):41-51. Available from: http://www.scialert.net/abstract/?doi=ijcr.2015.41.51

11. Lifiani R, Harahap U, Anjelisa $P$, Hasibuan Z, Satria D. Anticancer Effect of African Leaves (Vernonia Amygdalina Del.) To T47D Cell Resistant. 2018;11(1):25.

12. Opata MM, Izevbigie EB. Aqueous Vernomia amygdalina extracts alter MCF-7 cell membrane permeability and efflux. Int J Environ Res Public Health. 2006;3(2):174-9.

13. Rohin MAK, Ridzwan N, Jumli MN, Hadi NA, Hussin N, Zahary MN, et al. Screening Of bismillah leaf (Vernonia Amygdalina) extraction for antiproliferative activities in human glioblastoma brain cancer cell lines. Res J Pharm Biol Chem Sci. 2016;7(2):1084-9.

14. Rohin MAK Bin, Ridzwan N, Jumli MN, Hadi NA, Johari SATT, Latif AZA. Cytotoxicity study and morphological changes of different extraction for bismillah leaf (Vernonia amygdalina) in human glioblastoma multiforme cell line (u-87). Biomed Res. 2017;28(4):1472-8.

15. Izevbigie EB. Discovery of water-soluble anticancer agents (Edotides) from a vegetable found in Benin City Nigeria. Exp Biol Med (Maywood) [Internet].

Trop J Pharm Res, August 2020; 19(8): 1783 
2003;238(3):315-23. Available from: http://www.ncbi.nlm.nih.gov/pubmed/23598978\%5Cnhtt p://ebm.sagepub.com/content/230/1.toc.pdf

16. Adeoye A, Oyagbemi A, Omobowale T, Fagbohun $O$, Yakubu M, Adedapo A. Cell Proliferation and Cytotoxic Studies of Vernonia amygdalina on Vascular Smooth Muscle Cells and HT 29 Cell Lines. J Pharm Res Int [Internet]. 2018;21(6):1-10. Available from: http://www.sciencedomain.org/abstract/23990

17. Yedjou CG, Sims JN, Njiki S, Tsabang N, Ogungbe I V, Tchounwou PB. Vernonia amygdalina delile exhibits a potential for the treatment of acute promyelocytic leukemia. Glob J Adv Eng Technol Sci [Internet]. 2018 Aug [cited 2019 Aug 27];5(8):1-9. Available from: http://www.ncbi.nlm.nih.gov/pubmed/30310827

18. Wong FC, Woo CC, Hsu A, Tan BKH. The Anti-Cancer Activities of Vernonia amygdalina Extract in Human Breast Cancer Cell Lines Are Mediated through Caspase-Dependent and p53-Independent Pathways. PLoS One. 2013;8(10).

19. Yedjou C, Izevbigie E, Tchounwou P. Preclinical assessment of Vernonia amygdalina leaf extracts as DNA damaging anti-cancer agent in the management of breast cancer. Int $\mathrm{J}$ Environ Res Public Health. 2008;5(5):337-41.

20. Cameron KS, Howard CB, Izevbigie EB, Hill BJ, Tchounwou PB. Sensitivity and mechanisms of taxol- resistant prostate adenocarcinoma cells to Vernonia amygdalina extract. Exp Toxicol Pathol. 2013;65(6):759-65.

21. Johnson W, Tchounwou PB, Yedjou CG. Therapeutic mechanisms of Vernonia amygdalina delile in the treatment of prostate cancer. Molecules. 2017;22(10):113.

22. Gresham LJ, Ross J, Izevbigie EB. Vernonia amygdalina: Anticancer activity, authentication, and adulteration detection. Int $\mathrm{J}$ Environ Res Public Health. 2008;5(5):342-8.

23. Yedjou CG, Izevbigie EB, Tchounwou PB. Vernonia amygdalina-Induced Growth Arrest and Apoptosis of Breast Cancer (MCF-7) Cells. Pharmacol \&amp; Pharm [Internet]. 2013;04(01):93-9. Available from: http://www.scirp.org/journal/doi.aspx?DOI=10.4236/pp.2 013.41013

24. Yedjou CG, Tchounwou SS, Williams K, Tchounwou PB. Novel Cellular Staining Protocol and Antiproliferative effect of Vernonia amygdalina delile on lung and prostate cancer cells. Int J Eng Sci Res Technol. 2018;7(8):552-6.

25. Haugland RP. Chapter 8 - Nucleic Acid Detection and Analysis. In: The handbook: a guide to fluorescent probes and labeling technologies. Molecular probes; 2005. 